\title{
A burocracia e a aplicação da Lei de Terras: o caso da Província de São Pedro do Rio
}

\section{Grande do Sul}

\author{
Cristiano Luís Christillino ${ }^{1}$ \\ christillino@bol.com.br
}

\begin{abstract}
Resumo
A burocracia imperial do século XIX, sem estabilidade empregatícia formal e, inexistindo concursos públicos para o preenchimento das vagas, era dependente da cultura política clientelista daquele período. Desta forma, necessitava ter uma aceitação, tanto dos chefes políticos, que dirigiam as repartições públicas, quanto da elite político-econômica da época, para garantir a sua estabilidade nos seus cargos. Os expedientes existentes em torno da aplicação da Lei de Terras de 1850 não fugiram a esta lógica. O Regulamento de 1854 abria várias brechas que permitiam, na prática, a interferência decisiva dos agentes envolvidos nos processos de legitimações, oferecendondo margem às ações das redes clientelísticas locais nas quais estavam inseridos os "proprietários" locais. Ao mesmo tempo, a ação destes funcionários não poderia fugir à lógica proselitista da Coroa em vias de centralização.

Palavras chaves: burocracia, Lei de Terras de 1850, clientelismo.
\end{abstract}

\begin{abstract}
The imperial bureaucracy of century XIX, without formal employmentstability and inexisting public competitions for the vacant, was dependent of the culture politics client of that period. This form it needed in such a way to have an accetance of the heads politicians, who directed the public distributions how much of the politician-economic elite of the time to garantee its stability in its positions. The existing expedients around the application of the Land Law of de 1850 had not run away to this logic. The regulation of 1854 aponed some breaches that allowed, in the practical one, the decisive interference of the involved agents in the processes of legitimations, afford adge the actions of the local clientelist nets in which was inserted the "local

${ }^{1}$ Doutorando em História-UFF.
\end{abstract}


proprietors". At the same time, the action of these employees could not run away to the proselyte logic of the Crown in centralization ways.

Key words: bureaucracy, Law of Lands of 1850, clientelist.

A análise da aplicação da Lei de Terras de $1850^{2}$, no Brasil, a partir da análise empírica da Província de São Pedro do Rio Grande do Sul, e o papel da burocracia, neste processo, vêm nos auxiliar a esclarecer os mecanismos pelos quais a elite fundiária flexibilizou, em muitos casos, os dispositivos presentes nesta Lei, de acordo com os seus interesses no campo econômico e na esfera de poder. A Lei de Terras viria limitar, em seus artigos, as apropriações abusivas e as fraudes decorrentes desta, assim como outras tantas leis, era ambígua e plurívoca ${ }^{3}$, apresentando muitas brechas que, tanto poderiam ser utilizadas pelos pequenos posseiros, quanto pelos grandes "proprietários" nas suas construções de propriedades. Os beneplácitos deste último grupo não era um simples reflexo da sua condição social, mas o resultado de toda uma rede de relações clientelísticas, construídas a partir de hábeis ligações. Estas podem ser observadas na bibliografia referente ao período ${ }^{4}$ e também através da literatura da época. Em Memórias de um sargento de milícias $^{5}$, Manuel Antônio de Almeida faz uma boa descrição do clientelismo no Brasil, no início da década de 1850. O autor descreve um encadeamento existente de lealdades e de fidelidades (redes de relações pessoais), hierarquizadas em torno da esfera pública, num encadeamento que vai, desde o mais pobre indivíduo, até o Imperador, ou a sua cúpula dirigente. E, em meio a este caminho, estava uma incipiente e complexa burocracia do Estado, que teve um importante papel na acomodação dos interesses da aristocracia rural, ou parte dela. A aplicação da Lei de Terras veio ao encontro desta prática.

\footnotetext{
${ }^{2}$ Lei n ${ }^{\circ} 601$ de 20 de setembro de 1850, e regulamentada pelo Decreto $\mathrm{n}^{\mathrm{o}} 1318$ de 30 de janeiro de 1854 , conhecida como Lei de Terras de 1850.

${ }^{3}$ MOTTA, Márcia Maria Menendes. Nas fronteiras do poder: conflitos de terras e direito agrário no Brasil em meados do século XIX. Rio de Janeiro: Vício de Leitura; APERJ, 1998.

${ }^{4}$ GRAHAM, Richard. Clientelismo e política no Brasil do século XIX. Rio de Janeiro: Editora da UFRJ, 1997. CARVALHO, José Murilo de. A construção da ordem: a elite política imperial/ Teatro das sombras: a política imperial. 2.ed. Rio de Janeiro: Editora da UFRJ, Relume-Dumará, 1996.

${ }^{5}$ ALMEIDA, Manuel Antônio. Memórias de um sargento de milícias. Edição crítica de Cecília Lara. Rio de Janeiro: Livros Técnicos e Científicos Editora, 1978.
} 
Este emaranhado de redes de relações em torno do poder do Estado nos traz uma atribuição importante a este confiada: o poder de arbitrar os conflitos e os impasses da sociedade. Este aspecto realça a importância da inserção naquelas estruturas clientelísticas armadas em torno das repartições e órgãos estatais. A centralização política, empreendida pela coroa, não contava, inicialmente, com bases totalmente sólidas; dessa forma, a arbitragem sobre as divergências regionais lhe trouxeram enormes vantagens políticas, na medida em que estas se constituíram num verdadeiro poder de barganha junto a tais. Isto reforça a busca de inserção na estrutura clientelística do Estado, por parte das elites locais, intensificando o mesmo mecanismo, que, por sua vez, afirmava o poder da Coroa ${ }^{6}$. Na medida em que esta arbitrava tais impasses, abrindo a possibilidade de "flexibilizações", próprias do clientelismo, e garantindo concessões ao poder local, a Coroa intensificou a inserção de elementos deste na sua estrutura burocrática, o que lhe imprimiu uma característica proselitista, importante, a um Estado em plena centralização.

O próprio sistema bipartidário foi um aliado na centralização do poder, empreendida pela Coroa no Segundo Reinado. Embora houvesse o predomínio do Partido Conservador, na maior parte deste período, a possibilidade de se transferir cargos e outros beneplácitos, de um partido para outro, incentivou os mesmos grupos a buscarem a maior inserção possível nas estruturas do Estado. Mas ainda predomina, na historiografia, uma visão que indica a inexistência de grandes divergências entre os conservadores e os liberais ${ }^{7}$. A simples existência de um sistema bipartidário já nos aponta uma divergência entre dois grupos políticos. Estas diferenças, todavia ainda não foram analisadas com maior profundidade pela historiografia. Uma vez analisado, este sistema mostraria as possibilidades de seu uso como um poder de aliciamento pela Coroa, especialmente em torno das constantes trocas de ministérios e de presidentes de província. Isso nos mostra que a arena política estava permeada de buscas incessantes de benesses, e que, em torno dessas, girava a centralização do poder, pois, enquanto fazia concessões, a Coroa

\footnotetext{
${ }^{6}$ CHRISTILLINO, Cristiano Luís. Estranhos em seu próprio chão: o processo de apropriações e expropriações de terras na Província de São Pedro Do Rio Grande do Sul (o Vale do Taquari no período de 1840-1889). São Leopoldo, UNISINOS, 2004. Dissertação (Mestrado em História), Centro de Ciências Humanas, Universidade do Vale do Rio dos Sinos, 2004.

${ }^{7}$ Especialmente a partir do trabalho de GRAHAM, 1997, op. cit., o qual procura mostrar que o clientelismo era a chave do sistema político imperial, mas o mesmo não desenvolve com maior profundidade as diferenças existentes entre liberais e conservadores e como esta era utilizada como um poder de barganha pela Coroa.
} 
conquistava um número maior de adeptos. No caso da aplicação da Lei de Terras de 1850, não houve uma exceção à regra: esta também foi utilizada, em muitos casos, como um meio de negociação junto às elites locais.

Ao relegar as estruturas locais de poder à aplicação da Lei de Terras, como veremos, a Coroa cultivou essa característica, pois realizou importantes "concessões", mas, em última instância, era ela a responsável pela resolução dos litígios e "faltas", garantindo a sua arbitragem sobre os processos de legitimações. A própria conjuntura política, permeada pelo clientelismo, incentivou a busca de boas relações com os chefes do Governo e sua clientela para se conseguir o postergamento e a flexibilização dos dispositivos da Lei de Terras. Sabendo-se que o Estado utilizava estas inserções, mais como alianças e cooptação, em função da sua própria estrutura de poder, do que uma barganha em correlação acirrada de forças, a Lei de Terras trouxe, na sua execução, a expressão proselitista da administração imperial, levando em conta a realidade agrária complexa, das mais diferentes regiões do país, conforme assinala Márcia Motta ${ }^{8}$. A simples justificativa da fragilidade do Estado sobre as elites rurais, para analisar o insucesso da aplicação da Lei conforme a sua proposta original, o veto dos barões ${ }^{9}$, não explica aquele processo. Na regulamentação mostra que a Lei foi direcionada à inserção da camada proprietária nas redes de sustentação do Governo, o que permitiu, ou pelo menos incrementou, a sua centralização e afirmação política.

O nível de inclusão das elites, através das suas redes de relações pessoais, pode ser visualizado nas atividades dos agentes locais, aos quais era atribuído um grande poder de decisão. Estes, saídos dessa elite, garantiram, tanto as benesses por esta solicitada, quanto a sua dependência da mesma burocracia. Este laço se reforçou ao longo das atividades da Repartição Especial de Terras Públicas. E, ao passo que a mesma elite controla tais ações, ela própria passa a depender cada vez mais da sua inclusão na estrutura do Estado para garantir as suas prerrogativas, e muitos "favores". Neste sentido, a regulamentação da Lei de Terras, se não garantiu a inclusão da elite fundiária nas redes do Governo Imperial, veio reforçar o atrelamento daquela a este, pois, detrás da autonomia local, estava uma necessidade de apoio cada vez maior deste. Era esta elite que constituía, no caso da Província de São Pedro do Rio Grande do Sul, o

\footnotetext{
${ }^{8}$ MOTTA, 1998, op. Cit.

${ }^{9}$ CARVALHO, 1981, op. Cit.
} 
próprio aparato repressivo do Estado, e um importante contingente militar, indispensável ao Império Brasileiro frente aos conflitos platinos. A cooptação ou a conquista de aliados nesse grupo, era vital ao Estado naquele período.

A descentralização dos trabalhos de regularização fundiária, de acordo com a Lei de Terras, com base na esfera provincial, valorizou o papel dos funcionários e tornou alguns postos estratégicos para as redes clientelísticas locais. As figuras centrais da burocracia local são: o juiz comissário, o fiscal, o diretor geral e o inspetor geral da Repartição Especial de Terras Públicas, cargos criados pelo Regulamento e nomeados pelo presidente de província. As legitimações eram encaminhadas, pelos requerentes, ao juiz comissário, apresentando-se, quando possuíam, os títulos de concessões e transferência da área requerida ou o pedido de legitimação de posse. Aí então, o juiz comissário nomeava a comissão de verificação de cultura efetiva e morada habitual, para depois nomear a comissão de medição, formada por ele próprio, o agrimensor, o escrivão e o ajudante de corda. Realizada a medição, o juiz comissário emitia seu parecer e encaminhava o auto de medição à Repartição Especial de Terras Públicas, onde recebia o parecer do fiscal, do inspetor geral, do diretor geral (delegado da repartição) e, finalmente, o do presidente da província. Houve muitos casos que resultavam em pedidos de embargos, os quais eram julgados pelo juiz comissário e pelo municipal, podendo apelar-se ao presidente da província e ao ministro da agricultura ${ }^{10}$.

O juiz comissário era o elemento - chave das legitimações de terras. As suas informações, remetidas a Repartição, ou aquelas por ele negligenciadas, como veremos adiante, eram geralmente decisivas, nos respectivos processos. Segundo o Regulamento:

\footnotetext{
“Art. 34. Os juizes comissários das medições são os competentes:

1. $\left.{ }^{\circ}\right)$ para proceder á medição e demarcação das sesmarias ou concessões do Governo Geral ou Provincial sujeitas á revalidação e das posses sujeitas á legitimação;

$2 .^{\circ}$ ) para nomear os seus respectivos escrivães e os agrimensores, que com eles devem proceder ás medições e demarcações."
}

\footnotetext{
${ }^{10} \mathrm{O}$ art. $4^{\circ}$ do Regulamento fala da submissão da Repartição Especial de Terras Públicas ao Ministério dos Negócios do Império, mas os autos verificados por nós foram encaminhados ao Ministério da Agricultura.

${ }^{11}$ Secretaria da Agricultura RS. Coletânea da Legislação das Terras Públicas do Rio Grande do Sul. Porto alegre, 1961, p. 13.
} 
Além de ser importante nas medições de terras, sendo o chefe das mesmas e nomeando os seus executores, o juiz comissário funcionava como elo de ligação entre as figuras locais e o Governo Provincial, quando este elo já não havia. Era ele quem articulava a aproximação entre as partes. Sua importância local não se restringiu aos contatos e nomeações que propiciava; sua ação era fundamental, na afirmação de poder de muitos proprietários nos litígios com pequenos posseiros,

“Art. 42. Se porém as posses, que se acharem nas sesmarias, ou concessões, não tiverem em seu favor alguma das ditas exceções, o Juiz comissário fará proceder á avaliação das benfeitorias, que nelas existirem; e entregue o seu valor ao posseiro, ou competentemente depositado, se este o não quiser receber, as fará despejar, procedendo á medição de conformidade com o titulo da sesmaria, ou concessão.

Art. 43. A avaliação das benfeitorias se fará por dois árbitros nomeados, um pelo sesmeiro, ou concessionário, e outro pelo posseiro; e se aqueles discordarem na avaliação, o juiz comissário nomeará um terceiro árbitro, cujo voto prevalecerá, e em que poderá concordar com um dos dois, ou indicar novo valor, contanto que não esteja fora dos limites dos preços arbitrados pelos outros dois."

Desta forma, o juiz comissário tinha um papel fundamental na expropriação do lavrador nacional, quando houvesse litígio, pois era ele quem "avaliava" as precárias benfeitorias dos agricultores humildes, ou, em casos excepcionais, nomeava um árbitro de sua confiança que decidiria o valor "justo" das construções e roçados destes posseiros. Sem contar que o juiz comissário também poderia ser conivente com a incorporação dessas pequenas posses por outros requerentes, com base no seu poder pessoal e político, ignorando os direitos de ocupação adquiridos por aqueles. Mas, por que o juiz comissário agiria desta forma? Pelo simples fato de que, num espaço em que predominavam as redes clientelísticas, ligadas aos terratenentes locais, estes juízes também buscavam a permanência e a ascensão nas atividades nas quais estavam inseridos. Não seria interessante, para seu crescimento na hierarquia burocrática ${ }^{13}$, fazer frente à mesma elite. Assim, os juízes comissários não criaram grandes obstáculos à ação daqueles.

\footnotetext{
${ }^{12}$ Ibidem, p. 14.

${ }^{13}$ É importante lembrar que numa sociedade predominantemente rural como a do Brasil Império, os cargos públicos eram os postos de trabalho mais almejados por jovens egressos das camadas média e alta (alguns dos quais eram bacharéis em Direito e Medicina) por serem praticamente os únicos capazes de satisfazer os níveis de vida
} 
No que diz respeito à fiscalização dos autos de medições, os fiscais da Repartição Especial de Terras Públicas tiveram um papel considerável em torno das validações das mesmas, pois, dificilmente, um auto de medição, considerado "firme e valioso," por estes funcionários, seria contestado pelo diretor (delegado) da mesma Repartição e pelo presidente da província. As competências do fiscal podem ser visualizadas, resumidamente, no artigo $5^{\circ}$ do Regulamento.

\footnotetext{
"Art. 5. ${ }^{\circ}$ Compete ao Fiscal:

$\S 1 .^{\circ}$ Dar parecer por escrito sobre todas as questões de terras, de que trata a Lei n. ${ }^{\circ} 601$, de 18 de setembro de 1850, e em que estiverem envolvidos direitos e interesses do Estado e tiver de intervir Repartição Geral das Terras Públicas, em virtude deste Regulamento, ou por ordem do Governo.

$\S 2 .^{\circ}$ Informar sobre os recursos interpostos das decisões dos Presidentes das Províncias para o Governo Imperial.

$\S 3 .^{\circ}$ Participar ao Diretor-Geral as faltas cometidas por quaisquer autoridades, ou empregados, que por este regulamento têm de exercer funções concernentes ao registro das terras possuídas, a conservação, venda, medição, demarcação, e fiscalização das terras devolutas, ou que estão sujeitas à revalidação, e legitimação pelos arts. $4 .^{\circ}$ e $5 .^{\circ}$, da Lei n. ${ }^{\circ} 601$, de 18 de setembro de 1850 .

$\S 4 .^{\circ}$, Dar ao Diretor-Geral todos os esclarecimentos e informações, que forem exigidos para o bom and amento do serviço."14
}

O presente artigo mostra a importância do fiscal nos trâmites burocráticos que envolveriam as medições seria ele o principal conhecedor, na repartição, das consistências e inconsistências dos autos de medições. Nestes são evidenciados a importância de sua análise, na medida em que, na maioria dos casos, são ratificados os seus pareceres. Embora houvesse casos nos quais o julgamento do fiscal fosse desconsiderado ${ }^{15}$, a sua posição era importante na aprovação dos mesmos.

Enquanto o fiscal dava seu parecer sobre o processo, detectando ou não possíveis "erros", era o Delegado da Repartição Especial de Terras Públicas quem emitia o parecer final da

\footnotetext{
almejados. Alguns deles garantiam aposentadorias, uma concessão rara e que permitia aos seus possuidores a conservação de seus bens na velhice.

${ }^{14}$ Ibidem, p. 09-10.

${ }^{15}$ É o caso da medição de Vitorino José Ribeiro, Auto de Medição no 190. Autores: Vitorino José Ribeiro e Anna Emília Sampaio Ribeiro, 1860, Taquari. AHRS.
} 
Repartição. Sua posição tinha o peso da respectiva instituição e ele seria, na prática, o seu principal julgador, posto que os presidentes de província não permaneciam, em média, mais que 1 ano nos seus cargos e muitos eram provenientes de outras Províncias ${ }^{16}$. Assim, mesmo havendo alguns casos em que estes últimos deram um "canetasso" nos processos, geralmente tais presidentes, da Província de São Pedro do Rio Grande do Sul, acataram as decisões do delegado, principalmente por este ser nomeado pelo primeiro e exprimir a tática proselitista do Governo Geral. Neste sentido, uma ação rígida do delegado, em relação ás medições, poderia custar-lhe o próprio cargo, pois, a possibilidade de recurso ao Ministério da Agricultura e a ação junto ao presidente da província, poderia, numa manifestação ampla de descontentamento (no caso de várias reclamações), fazer a pressão necessária para a sua demissão ou remoção, uma vez que sua conduta fugiria aos objetivos do Estado. Mais uma vez nos deparamos com o caso de uma peça chave da burocracia, na condução das legitimações de terras, que também precisava engajar-se nas estruturas de poder local, embora o peso das suas competências de decisões, para garantir a sua estabilidade e permanência na burocracia do Império.

Outro aspecto que chama atenção na discussão sobre os funcionários da Repartição Especial de Terras Públicas, para além da questão do estreitamento de redes de relações pessoais, é o que diz respeito à remuneração dos mesmos, especialmente os do Inspetor Geral. O trabalho deste possuía uma grande importância nos Processos de Legitimações:

\footnotetext{
"Art. 11. Em cada distrito haverá um inspector-geral das medições, ao qual serão subordinados tantos escreventes, desenhadores e agrimensores quantos convier. $\mathrm{O}$ inspector-geral será nomeado pelo Governo, sob proposta do diretor-geral. Os escreventes, desenhadores e agrimensores serão nomeados pelo inspector-geral, com aprovação do presidente da província." ${ }^{17}$
}

Mesmo assim eles não tinham um ganho específico:

\footnotetext{
${ }^{16}$ Isto pode ser percebido nos Relatórios de Presidentes de Província do período de 1846 a 1889. AHRS.

${ }^{17}$ Secretaria da Agricultura RS, 1961, op. Cit., p. 10.
} 
“Art. 21. Os inspetores não terão ordenado fixo, mas sim gratificações pelas medições que fizerem, as quais serão estabelecidas sob proposta do diretor-geral das terras públicas, com atenção ás dificuldades, que oferecerem as terras a medir." 18

Desta forma, recebendo, em função da "produtividade" do seu trabalho, não seria interessante aos inspetores estabelecerem limites às ações dos grileiros ${ }^{19}$, pois também receberiam em função das medições destes. Isso pode ser claramente verificado na confecção dos mapas das medições, onde se constata exemplos dos mesmos, produzidos na mesma época, pois, tanto apresentam detalhes especificados em torno das atividades agropecuárias existentes na área, quanto às plantas sem quaisquer referência sobre a ocupação efetiva, quando o primeiro caso não era interessante ao proprietário, o que mostraria a legitimação de áreas não ocupadas ${ }^{20}$. Isso ocorria nos próprios autos das medições, nos quais eram realizados as descrições dos rumos apurados por esta, onde há muitos casos em que apenas se ratifica os "antigos rumos e marcos",21. Este mesmo sentido vem corroborar o trabalho do agrimensor, que também recebia em função do número de medições que realizava. Segundo o Regulamento:

“Art. 35. Os agrimensores serão pessoas habilitadas por qualquer escola nacional ou estrangeira, reconhecida pelos respectivos governos, e em que se ensine topografia. $\mathrm{Na}$ falta de titulo competente serão habilitados por exame feito por dois oficiais do corpo de engenheiros ou por duas pessoas que tenham o curso completo da Escola Militar, sendo os examinadores nomeados pelos presidentes das províncias." 22

Este artigo, não só habilita os militares para as medições, em casos de ausência de civis preparados para tal, como também abre caminho para a utilização destes nas medições de seus superiores. É preciso salientar que as diferenças existentes entre a Guarda Nacional e o Exército,

\footnotetext{
${ }^{18}$ Idem, p. 11.

${ }^{19}$ A grilagem de terras é um dos principais legados do século XIX. MOTTA, Márcia Maria Menendes. A grilagem como legado. In: . \& PIÑEIRO, Theo. Voluntariado e universo rural. Rio de Janeiro: Vício de Leitura, 2001, vol. 1, p. 75-91.

${ }^{20}$ É o que ocorre com o Auto de medição No 478 do Tenente Coronel Luiz Alves de Oliveira Bello em 1877, AHRS, no qual é presente um mapa "limpo", sem mostrar a área efetivamente ocupada.

${ }^{21}$ Isto vai ocorrer no Auto de Medição no 390, como autor Antonio Fialho de Vargas em 1874, em que o auto da medição possui apenas 2 páginas, enquanto que na maioria das mesmas possuem 20 ou mais.

${ }^{22}$ Secretaria da Agricultura RS, 1961, op. Cit., p. 13.
} 
neste momento, mas muitos dos integrantes deste eram indicados pelos daquela. Um oficial do corpo de engenheiros (ao invés dos dois previstos pelo Regulamento) que fosse medir a área de um tenente coronel, não criaria empecilhos ao mesmo, o que era fruto de toda uma hierarquia rígida do meio militar. Tal procedimento não seria interessante a capitão algum. Por estas razões os agrimensores não registraram, nos autos de legitimações pesquisados, nenhuma discordância das medições que realizaram, pois dependiam da remuneração a ser recebida dos requerentes das mesmas e, em muitos casos, até de uma indicação para uma patente no exército ou na Guarda Nacional. Isso também ocorria em função do poder político, ou simplesmente econômico de alguns integrantes da elite. Antonio Cândido ${ }^{23}$ nos traz um bom exemplo disto, na biografia de um funcionário da monarquia: Antônio Tolentino que foi um burocrata marcado pela sua honestidade e competência para os moldes da época, mas ao assumir o posto de Chefe da Alfândega do Rio de Janeiro, tentou limitar a ação de contrabandistas naquela instituição, inclusive o principal deles: o "comerciante" Romaguera. Este famoso contrabandista era detestado por D. Pedro II, mas, ao ser confrontado por um burocrata do Império, que o denunciou por sonegação de impostos e contrabando, foi defendido judicialmente pelo prestigioso Ministro Ângelo Muniz da Silva Ferraz. Embora este não tenha conseguido defender seu cliente, a contanto, o fato, causou a demissão de Antonio Tolentino daquela repartição, em função das represálias ao último. Se isto ocorria sob o teto da Corte, podemos imaginar a força desta elite sobre a burocracia, nos locais distantes das barbas do Imperador.

A figura central do aparato burocrático, e que vai ter, direta ou indiretamente, um papel decisivo, na aprovação dos processos de legitimações, é o presidente de província, pois era ele quem julgava esses casos:

\footnotetext{
“Art. 48. Estes recursos não suspenderão, a execução: ultimada ela, e feita a demarcação, escritos nos autos todos os termos respectivos, os quais serão também assinados pelo agrimensor, organizará este o mapa, que a deve esclarecer; e unidos aos autos todos os requerimentos escritos, que tiver havido, e todos os documentos apresentados pelas partes, o juiz comissário a julgará por finda; fará extrair um traslado dos autos para ficar em poder do escrivão, e remeterá os originais ao presidente da província ainda quando não tenha havido interposição de recurso.
}

${ }^{23}$ CANDIDO, Antônio. Um funcionário da monarquia: ensaio sobre o segundo escalão. Rio de Janeiro: Ed. Ouro Sobre Azul, 2002. 
Art. 49. Recebidos os autos pelo presidente, e obtidos por ele todos os esclarecimentos, que julgar necessários, ouvirá o parecer do delegado diretor-geral das terras públicas, e este ao fiscal respectivo, e dará a sua decisão, que será publicada na Secretaria da Presidência, e registrada no respectivo livro da porta."24

Possuindo este poder de decisão, o presidente de província vai agregar, em torno de si, toda uma esfera de interesses em relação à legitimação de terras e à afirmação de propriedade da elite rural. Era ele quem representava, mais diretamente, os interesses proselitistas do Governo Imperial, sendo interlocutor entre este e a elite local. A própria política da Coroa, em realizar um constante rodízio de presidentes de província, geralmente com elementos de outras regiões, visava impedir a criação de vínculos entre estes e o poder local ${ }^{25}$, o que fez crescer as buscas de inserção nas redes clientelísticas em torno do Estado. Uma vez sendo nomeado, ao invés de eleito, o presidente de província geralmente foi fiel ao projeto da Coroa e ao seu pragmatismo agregador, sempre buscando a conciliação e o apoio local a mesma.

\footnotetext{
"Uma tarefa comum para um presidente provincial consistia em selar cuidadosamente acordos entre facções rivais locais, possibilitando a ambas participar dos espólios dos cargos. Se bem idealizado esse arranjo tinha a vantagem de evitar a violência, ao mesmo tempo em que se mantinha o controle.",26
}

Assim, o presidente da província recebia informações detalhadas sobre a arena de alianças locais, para então agir junto à mesma Unidade Imperial tornando-se o centro das atenções clientelísticas (cada ato em torno do qual vai estar repleto de interesses particulares). E agia habilidosamente, numa administração que buscava a maior adesão possível da camada de possuidores de terras, ainda mais na Província de São Pedro do Rio Grande do Sul, onde a Farroupilha mostrou, além do poder bélico local, um claro desejo de se independizar do restante do Império ${ }^{27}$. E nessa Província, havia um forte contingente militar, o qual garantia a estabilidade política local e era fundamental nas ações militares internas e externas do Governo Geral, como a Guerra do

\footnotetext{
${ }^{24}$ Secretaria da Agricultura RS, 1961, op. Cit., p. 15.

25 CARDOSO, Fernando Henrique. Capitalismo e Escravidão no Brasil Meridional: o negro na sociedade escravocrata do Rio Grande do Sul. Rio de Janeiro: Paz e Terra, 1977.

${ }^{26}$ GRAHAM, 1997, op. cit., p. 177.

${ }^{27}$ PADOIN, Maria Medianeira. Federalismo gaúcho: fronteira platina, direito e revolução. São Paulo: Companhia Editora Nacional, 2001.
} 
Paraguai. Os altos postos militares, como os de capitães e de tenentes coronéis, vão ser preenchidos por grandes possuidores de terras, ou por outros que receberão grandes áreas "devolutas," como gratificação pelos serviços prestados na Guarda Nacional. Não era interessante, para um Estado que estava em vias de centralização, como era o caso do Brasil Imperial da segunda metade do século XIX, desconsiderar o apoio do comando local da Guarda Nacional, o que representaria, na soma destas perdas locais, uma falta de apoio militar considerável e fundamental. Neste sentido, a figura do presidente de província, em suas ações sobre os processos de legitimações, estavam direcionadas no sentido de alargar e reforçar as redes de aliança em torno do Estado, sendo conivente com a ação de grileiros e especuladores, quando preciso, para atingir este intento. Desta forma, por mais estranho que pareça, o presidente de província não vai barrar rigorosamente a ação de grileiros desta camada de possuidores de terras, isso fugiria à lógica apresentada anteriormente. Neste mesmo sentido, Antônio Cândido ${ }^{28}$ nos traz mais um exemplo do seu biografado, Antonio Tolentino, sobre os limites da burocracia em relação às elites terratenentes locais. Este burocrata do Império, após a utilização de várias ligações clientelísticas, e pelo matrimônio, adquiriu um importante capital político e financeiro. Ocupou alguns cargos do baixo escalão e se tornou deputado provincial, cargo através do qual obteve um grande destaque. Isto, somado a outros fatores, como as alianças, o levaram a ser indicado como Governador da Província do Rio de Janeiro. Uma vez assumindo o cargo, Tolentino apresentou uma proposta de criação de concursos para seleção de funcionários públicos naquela Província, o que abalou os deputados desta, que provinham de relações clientelísticas, nas quais a distribuição de tais cargos eram fundamentais, para a manutenção das suas redes de clientela. Assim toda a Assembléia ficou contra o proponente, forçando, assim, a sua demissão. A atuação de Tolentino, em seu cargo principal, fora limitada pelo rompimento com as sólidas redes clientelísticas, estabelecidas em torno do plano político. Ele não conseguiu conciliar os seus planos políticos com aqueles das elites locais. O que lhe custou o seu cargo, e o amargo ostracismo, pois, ousou contrariar os interesses mais pragmáticos da socialite carioca, como foi o caso da distribuição de cargos, sem êxito. Outros tantos burocratas, muitos deles prestigiosos, não cometeram o mesmo erro.

\footnotetext{
${ }^{28}$ CÂNDIDO, 2002, op. cit.
} 
O mecanismo acima descrito pode ser visualizado num dos processos de legitimação empreendidos pelo Tenente Coronel Vitorino José Ribeiro, que comandava um importante núcleo da Guarda Nacional, no Vale do Taquari, e havia fundado a "Colônia da Estrella", a qual, em breve, tornar-se-ia uma das mais prósperas colônias particulares da Província. Já tendo legitimado uma área com mais de 10.000 hectares, em 1861, no Vale do Taquari, realizou um outro pedido para uma área de 508 hectares, em $1862^{29}$, na mesma região. A posse pode, nos parecer singela, diante da outra área do referido Ten. Cel., mas era o suficiente para a divisão em 11 lotes coloniais, de 48 hectares cada um, numa área muito fértil para a agricultura ${ }^{30}$. Seu pedido não foi aceito pelo Delegado da Repartição Especial de Terras Públicas, o qual alegou que a área fora adquirida dos primeiros concessionários, após a publicação do Regulamento de 1854, sem ter sido legitimada pelos mesmos. O Tenente Coronel Vitorino também teve negado o seu recurso enviado junto a esta Repartição Especial de Terras Públicas. Mas após um longo trajeto na burocracia da Província, o mesmo processo foi aprovado pelo Conselheiro Antão Fernandes Leão, Presidente da Província de São Pedro do Rio Grande do Sul, em 25 de abril de 1862, desconsiderando as sentenças realizadas por aquela Repartição.

O Tenente Coronel André Alves Leite de Oliveira Bello, mais tarde Barão do Gravataí, comandante da Guarda Nacional e membro de uma família que possuía um grande prestígio junto ao Governo Provincial, (seja por sua liderança militar ou pela carreira política de seu irmão, Luiz Alves Leite de Oliveira Bello), era formado em Direito e atuava como desembargador foi deputado provincial, nos anos de 1846 a 1849, e, novamente, no período de 1854 a 1859, já no interregno das duas legislaturas. O Dr. Bello foi deputado da Câmara do Império, sendo VicePresidente da Província de São Pedro do Rio Grande do Sul, por duas vezes, em 1852 e $1856^{31}$. De família bem relacionada, também irá se valer de seus "contatos" para assegurar a afirmação de suas áreas de terras, localizadas em regiões próximas a Porto Alegre, como na Serra do Caí, em Triunfo, Aldêa dos Anjos (Gravataí) e outra área de matas com mais de 1000 hectares na Serra de Taquari (Venâncio Aires). Formada por terras florestais, próprias para a agricultura, a

\footnotetext{
${ }^{29}$ Auto de Medição no 190. Autores: Vitorino José Ribeiro e Anna Emília Sampaio Ribeiro, 1860, Taquari. APERS.

${ }^{30}$ Segundo o tamanho dos lotes vendidos a imigrantes neste período contidos nos Livros de Tabelionato do Cartório Cível e Crime de Taquari, talões 01 a 05. APERS.

${ }^{31}$ PICCOLO, Helga Iracema L. Coletânea de discursos parlamentares da Assembléia Legislativa de São Pedro do Rio Grande do Sul: 1835/1889. Porto Alegre: Assembléia Legislativa do Estado do Rio Grande do Sul, 1998.
} 
gleba vai sofrer uma rápida valorização, com a criação da Colônia Provincial Monte Alverne, em 1859, num terreno adjacente, e ainda por estar localizada ao lado da povoação de São Sebastião Mártir, futura Venâncio Aires. Dessa forma o Ten. Cel. Bello irá adquirir a referida extensão em 1861 e 1862. Neste último ano, já vai entrar com o pedido de legitimação junto a Repartição Especial de Terras Públicas ${ }^{32}$. A compra, realizada aos sobrinhos herdeiros de Praxedes Henriqueta de Escovar que, curiosamente, teria recebido esta grande área como doação (em função de ser "pobre e solteira"), do seu padrinho, o Padre Amaro de Souza Machado, em 1825, 4 anos após este ter recebido a concessão da área, até então inóspita, localizada a mais de 70 quilômetros de Taquari. Sem boas vias de acesso, tendo-se que atravessar vários arroios, sem pontes, este irá se constituir num ótimo negócio, pois no momento, a mesma área estava recebendo melhoramentos infra-estruturais (em função do que estava ocorrendo na Colônia de Mont'Alverne e na vila de São Sebastião Mártir, próximas daquela área), como estradas e pontes. Ainda em 1865 será nela fundada a Colônia Santa Emília. Embora já loteada e boa parte vendida, o processo referente a essa área permaneceu parado, na Repartição, desde 1862 e, somente foi julgado em 1872, tendo parecer contrário. Em 1876, a viúva do Ten. Cel. Bello, Maria Emília Pereira Bello, Baronesa do Gravataí, irá dar continuidade ao processo, no qual o seu filho João Alves de Oliveira Bello fará a reclamação ao Governo, da incorporação de $25 \%$ de sua área, na medição das terras do primeiro. As "faltas" não foram totalmente supridas e o mesmo processo fora aprovado em 1877. Quanto à reclamação da medição, somente há o registro de que o Estado fora "prudente," na medição, em que poderia haver prejuízo do Cel. Bello, não havendo qualquer referência sobre a resolução definitiva do impasse nesse ano, criando-se uma questão, postergada para um outro momento mais adequado. O tempo, em muitos casos, era um aliado importante aos processos em curso.

Mas não foram estes, casos isolados; houve vários outros concomitantes. Logo, se o Presidente da Província negasse legitimações importantes como estas apresentadas, faria com que boa parte dos comandantes militares do Vale do Taquari, que possuíam um grande poder de "alistamentos voluntários" para os trabalhos da Guarda Nacional, deixassem as fileiras da força militar do Império, na medida em que seriam contrariados os interesses de um de seus chefes, ou até mesmo de outros tantos que também poderiam ter seus pedidos de legitimações negados, o

\footnotetext{
${ }^{32}$ Auto de medição No 478 do Tenente Coronel Luiz Alves de Oliveira Bello, 1877, Taquari. AHRS.
} 
que, em tese, seria um erro para um Estado que dependia da aliança com o poder local para garantir a sua estabilidade e a sua centralização. O Brasil possuía uma abundante extensão de terras devolutas de dimensões incalculáveis. Assim, um grupo de soldados, lutando no Prata, era muito mais importante, ao Governo Imperial, do que alguns milhares de hectares cobertos de "matos e tigres". E os presidentes de província tinham consciência disso.

Em torno do presidente de província, se alicerçava toda uma rede de relações pessoais e o Regulamento de 1854 vem reforçar ainda mais, esses laços, na medida em que foram esses que tiveram a incumbência de nomear pessoas, para os cargos da Repartição, e ainda os juízes comissários.

“Art. 30. Obtidas as necessárias informações, os presidentes das províncias nomearão para cada um dos municípios, em que existirem sesmarias ou outras concessões de Governo Geral ou Provincial, sujeitos á revalidação, ou posses sujeitas á legitimação, um juiz comissário de medições." 33

A partir destas nomeações, se estruturou, localmente, toda uma rede de relações pessoais que foram fundamentais para as afirmações das "propriedades" em vias de legitimações, além das outras nomeações realizadas para os cargos da Repartição Especial de Terras Públicas.

O Regulamento de 1854 mostra uma série de dispositivos que se constituíam em verdadeiras brechas à aplicação da Lei. Foram abertas "exceções" que, na prática, garantiram a anulação de algumas disposições da mesma. Nas questões de revalidação:

“Art. 27. Estão sujeitas à revalidação as sesmarias ou outras concessões do Governo Geral ou Provincial que, estando ainda no domínio dos primeiros sesmeiros ou concessionários, se acharem cultivadas ou com principio de cultura e morada habitual do respectivo sesmeiro, ou concessionário, ou de quem o represente, e que não tiverem sido medidas e demarcadas.

Excetuam-se, porém, aquelas sesmarias ou outras concessões do Governo Geral ou Provincial que tiverem sido dispensadas das condições acima exigidas por ato do poder competente; e bem assim, as terras concedidas à companhia para estabelecimento de colônias, e que forem medidas e demarcadas dentro dos prazos da concessão.”34

\footnotetext{
${ }^{33}$ Secretaria da Agricultura RS, 1961, op. Cit., p. 13.

${ }^{34}$ Ibidem, p. 12.
} 
Mesmo restringindo as revalidações das concessões realizadas, o Regulamento abre brechas para a validação de áreas não passíveis de legitimação, mas que poderiam ser enquadradas nestas “exceções”. Isso assegurou a não realização de verificação de cultura efetiva e morada habitual, em boa parte dos processos de legitimações, o que permitia a inclusão de áreas não ocupadas pelos seus requerentes, ferindo um dos princípios básicos da Lei, que era impedir a apropriação indevida de terras pertencentes ao Governo Geral.

Outra brecha apresentada pelo Regulamento, na qual o papel da burocracia seria fundamental, é em relação aos prazos marcados. Eles são importantes, na medida em que estabelecem o limite temporal de pedidos de revalidação que, em tese, colocaria as áreas não legitimadas na situação de "caída em comisso", ou seja, áreas de ocupação ilegal, pertencente ao Estado.

"Art. 58. Findos os prazos, que tiverem sido concedidos, os Presidentes farão declarar pelos comissários aos possuidores de terras, que tiverem deixado de cumprir a obrigação de as fazer medir, que eles têm caído em comisso, e perdido o direito a serem preenchidos das terras concedidas por seus títulos, ou por favor da Lei n. ${ }^{\circ} 601$, de 18 de setembro de 1850 , e desta circunstância farão as convenientes participações ao delegado diretor-geral das terras públicas, e este ao referido diretor, a fim de dar as providências para a medição das terras devolutas, que ficarem existindo em virtude dos ditos comissos.",35

Mesmo sendo rigoroso ao que respeita aos prazos marcados, apontando para a agilidade dos processos, o Regulamento abria, mais uma vez, exceções que, na prática, iriam viabilizar o postergamento dos mesmos prazos.

“Art. 32. Feita a nomeação dos juizes comissários das medições, o presidente da província nomeará o prazo em que deverão ser medidas as terras adquiridas por posses sujeitas á legitimação, ou por sesmarias, ou outras concessões, que estejam por medir e sujeitas á revalidação, marcando maior ou menor prazo, segundo as circunstâncias do município, e o maior ou menor número de posses e sesmarias sujeitas á legitimação e revalidação que ai existirem.

\footnotetext{
${ }^{35}$ Ibidem, p. 15.
} 
Art. 33. Os prazos marcados poderão ser prorrogados pelos mesmos presidentes, se assim o julgarem conveniente; e neste caso a prorrogação aproveita a todos os possuidores do município para o qual for concedida." ${ }^{, 36}$

Estes postergamentos, não só retardaram a aplicação da mesma Lei, como também imprimiram um caráter de inércia, traduzido pela própria lentidão dos trâmites burocráticos, que sempre prorrogavam o tempo para a conclusão dos trabalhos, sendo que, na Província de São Pedro do Rio Grande do Sul, não haviam sido, definitivamente, concluídos todos os processos no momento da Proclamação da República. Esta demora, também, permitia ao autor do processo esperar o momento ideal (em que tivesse uma pessoa "confiável" na posição de avaliador do mesmo) para dar andamento ao seu caso, que estava parado na Repartição Especial de Terras Públicas, escolhendo o momento mais propício para a sua aprovação. Esta demora poderia ocorrer de dois modos: nos trâmites da burocracia, como vimos anteriormente ou no próprio ato de aguardar o momento ideal para iniciar o processo, o popular "ficar na moita". O Ten. Cel. Joaquim Alves Xavier ${ }^{37}$, enquanto herdeiro dos seus sogros, (o Cap. Francisco Silvestre Ribeiro e sua esposa Anna Sallazar Ribeiro, os quais possuíam ainda uma outra área, que fazia rumo com a Fazenda São Gabriel, loteada e comercializada, ainda em vida da última) e também como representante dos outros herdeiros (embora não conste qualquer procuração neste sentido no processo de legitimação ou mesmo o nome desses "outros" - A área mencionada era uma ponta de mata, denominada Travesseiro, com 6.629 hectares, localizada na região serrana do Alto Taquari e nela já havia sido criada a Colônia Travesseiro em $1879^{38}$ ), assim como vários outros grandes "proprietários" do Alto Taquari, preferiu não legitimar a sua área, no período próximo posterior à Lei de Terras. Tanto em função das redes, nas quais estavam assentadas a sua família, como pela própria inconsistência da argumentação de posse. Ocorre que, em 1880, José da Silva Mello Guimarães, ao proceder a medição de sua área, incorporou parte daquela, pretendida pelo autor, o que o fez entrar com um pedido de embargo. O Ten. Cel. Antonio Vítor de Sampaio Mena Barreto também teria avançado sobre a área de medição que realizou nas terras referentes às ditas posses de seus sogros. Tendo suas posses, ou terras pretendidas, ameaçadas por

\footnotetext{
${ }^{36}$ Ibidem, p. 13.

${ }^{37}$ Auto de Medição no 2017. Autor: Joaquim Alves Xavier, ano 1887, AHRS.

${ }^{38}$ SCHIEROLT, José Alfredo. Revolução Federalista no Vale do Taquari. In: Anais do IV Simpósio da História da Imigração e Colonização Alemã no Rio Grande do Sul. São Leopoldo: Rotermund, 1987.
} 
oponentes respeitáveis, o Ten. Cel. Joaquim Alves Xavier entrou com um pedido de medição, no início da década de 1880, o qual foi "extraviado" na Repartição Especial de Terras Públicas. Resolvido os seus embargos contra a medição dos primeiros, ele entrou com um pedido de legitimação, em 1886, o qual foi julgado e aprovado, em 1887, pelo Presidente da Província, o Dr. Rodrigo Azambuja Villanova, que possuía área de terras próxima à posse do autor e, provavelmente, seria um indivíduo de sua "rede". Isto se deve ao fato do Ten. Cel. Joaquim Alves Xavier ser primo do Ten. Cel. Primórdio Centeno de Azambuja, que, por sua, vez era sogro daquele presidente provincial, e também por terem, os Centeno de Azambuja alguns desafetos com o Ten. Cel. Mena Barreto, em função dos litígios de terras do então Major Primórdio com a sua irmã Maria José Sampaio Ribeiro Teixeira ${ }^{39}$. Dessa forma, era importante, ao próprio Dr. Villanova, reforçar as suas alianças no Vale do Taquari para garantir as suas estratégias familiares e a sua própria afirmação de propriedade, pois não legitimou a sua área pela via burocrática, uma vez que a mesma não possuía títulos, e nem posse efetiva, o que o obrigava a consolidá-la, através do seu respeito pessoal.

O objetivo central da Coroa era o de utilizar o Regulamento como mais um instrumento que auxiliasse a sua centralização. Não através da imposição das disposições nele previstas sobre a camada de possuidores de terras, mas sim pela inserção desses elementos na estrutura do Estado, através da busca de flexibilização dos seus dispositivos (e em alguns casos, até mesmo de fraudes) ou postergamento das decisões, visando aos seus interesses particulares. A regra não era impor uma ação sistemática, mas esperar a busca da utilização desta pelos proprietários, segundo os seus interesses, de modo que estariam objetivando um "apoio" e assim garantindo um compromisso de lealdade junto ao Estado, no qual seria mais interessante preservar a estrutura agrária existente do que contestá-la. Desta forma, era interessante ao Governo garantir a possibilidade de recursos às decisões dos presidentes de província (da esfera burocrática provincial), o que asseguraria uma busca de "contatos" cada vez maior pelos requerentes junto aos órgãos públicos centrais, uma vez que não havia um corpo judiciário desvinculado do executivo e, no caso das legitimações de terras, foi criada uma instância própria, uma espécie de judiciário dentro do próprio executivo, num momento em que não havia uma separação entre os

\footnotetext{
${ }^{39}$ Auto de Medição n ${ }^{\circ}$ 48. Autor: Maria José Sampaio Ribeiro Teixeira, 1861, Taquari. AHRS. Auto de Medição no 643. Autor: Primórdio Centeno de Azambuja, 1875, Taquari. AHRS.
} 
dois poderes. No caso da aplicação da Lei de Terras, criou-se um judiciário dentro da própria burocracia do Estado, sendo este controlado pela direção política do mesmo. Isto era garantido no Artigo 52:

“Art. 52. Das decisões do presidente da província da-se recurso para o Governo Imperial. Este recurso será interposto em requerimento apresentado ao secretário da presidência, dentro de dez dias, contados da data da publicação da decisão na secretaria; e sendo assim apresentado, suspenderá a execução da decisão; enquanto pender o recurso, que será remetido oficialmente por intermédio do Ministro e Secretário de Estado dos Negócios do Império." 40

Nenhum recurso passaria pelo "judiciário"; apenas pelas repartições do Governo. Assim, tal processo era comandado por estas. A este fator agrega-se, além das questões referentes aos prorrogamentos de prazos, as vendas e fixações de preços das terras públicas. Estes pontos, ao serem "direcionados pela esfera local”, davam uma grande margem de ação a essa burocracia.

Ao Estado, seria importante a conservação das terras públicas, seu conhecimento e controle. Estes eram quase impossíveis, postos que aquelas eram terras que sobraram das medições de particulares. E o Estado ainda colocou nas mãos desses proprietários locais o controle sobre essas terras públicas:

\footnotetext{
“Art. 87. Os juízes municipais são os conservadores das terras devolutas. Os delegados e subdelegados exercerão também as funções de conservadores em seus distritos e, como tais, deverão proceder ex officio contra os que cometerem os delitos de que trata o artigo seguinte e remeter, depois de preparados, os respectivos autos ao juiz municipal do termo para o julgamento final."
}

Ao relegar aos juízes municipais a conservação das suas terras, o Estado estava entregando, aos "proprietários" locais, o controle sobre uma fonte essencial à ampliação e à manutenção do patrimônio e do poder destes, uma vez que, a incorporação de novas áreas, possibilitava a exploração agropecuária e, assim, a sua comercialização, ou mesmo a fidelidade e a lealdade de quem nela trabalha. Isto porque os juízes municipais, em boa parte dos casos, eram os próprios

\footnotetext{
${ }^{40}$ Secretaria da Agricultura RS, 1961, op. Cit., 15.

${ }^{41}$ Secretaria da Agricultura RS, 1961, op. cit., p. 19.
} 
fazendeiros ou então elementos de suas redes e, muitas vezes, poderiam substituir o juiz de direito:

\begin{abstract}
"A historiografia tem mostrado como não era difícil para o juiz municipal substituir por impedimento ou falta um juiz de direito. A ação patrocinada pela própria estrutura política, administrativa e judiciária do estado Imperial subordinou o mandato das autoridades judiciárias às elites locais, apesar de o Código do processo prever que 'os juizes de direito não serão tirados de uma para outra comarca, se não por promoção aos lugares vagos das Relações, a que tinham direito, ou quando a utilidade publica assim o exigir (cap. IV, art. 45)."
\end{abstract}

O juizado municipal de Taquari foi ocupado, ao longo do terceiro quartel do século XIX, pela elite rural, o que também vinha ocorrendo em outras regiões da Província. Somente em 1878 é que aquele juizado passa a ser conduzido por um juiz de direito para substituir o Ten. Cel. Raphael Fortunato Xavier Azambuja ${ }^{43}$. Este último, pertencente à conhecida família Azambuja (irmão do Major Primórdio e filho de Laura e João Xavier Azambuja), ao resguardar o patrimônio público, também estava defendendo os interesses da sua rede de relações pessoais e da sua parentela. Ocorre que essa família possuía uma concessão conhecida como Fazenda São Gabriel, acima do Arroio Sampaio, na margem direita do Rio Taquari. Esta área limitava-se, aos fundos, com as ditas terras públicas, que também se limitavam com as terras do seu irmão Major Primórdio Centeno de Azambuja, e do seu aliado, Antonio Fialho de Vargas, um dos maiores, ou o maior, comerciante de terras da Região do Vale do Taquari. Este grupo estava interessado em não demarcar as terras devolutas, o que lhes barraria o avanço sobre tais áreas. Mesmo que o Ten. Cel. João Xavier Azambuja declarasse nos registros paroquiais ${ }^{44}$ que sua área limitava-se aos fundos, com terrenos devolutos, e que não tenha passado pela Câmara Municipal de Taquari nenhum pedido de concessão, para a declaração desta, se o terreno era ou não devoluto, o Ten. Cel. Raphael Fortunato Xavier Azambuja, juntamente com outros, fundou a Colônia Nova Berlin,

\footnotetext{
${ }^{42}$ IVO, Isnara Pereira. Poder local e eleições na imperial vila da Vitória durante o século XIX. In: Edições UESB, Vitória da Conquista-BH, v. 01, n. 01, 2001, p. 201-223.

${ }^{43}$ LEMOS, Francisco de Faria. Relatório com que o Exmo. Snr. Desembargador Francisco de Faria Lemos passou a administração da Provincia ao Exmo. Snr. Dr. João Chaves Campello, $2^{o}$ vice-presidente, no dia 10 de fevereiro de 1878. Porto Alegre: Typographia do Jornal do Commercio, 1878.

${ }^{44}$ Registro Paroquial de Terras da Freguesia de Santo Amaro número 270. APERS.
} 
na mesma área até então considerada devoluta e que ele próprio era o responsável pela sua preservação. Não conseguimos encontrar qualquer referência à forma de acesso à "propriedade" da área pelo mesmo Juiz Municipal; apenas os registros de venda dos lotes coloniais.

A ocupação destes cargos era estratégica para a elite fundiária local. E, mesmo os juizes de direito, muitas vezes inseridos nas redes dessa elite, irão facilitar tais práticas. A ação desses profissionais, na Província de São Pedro do Rio Grande do Sul, foi muitas vezes barrada por aqueles. Nos Campos de Cima da Serra, em 1870, foi assassinado o Juiz de Direito da Vila de Lagoa Vermelha, Dr. Antônio de Pádua Holanda Cavalcanti, em função dos limites, que este vinha tentando impor, à ação dos fazendeiros locais, onde o réu, reconhecidamente assassino da vítima, foi absolvido ${ }^{45}$. Estas disputas também atingiram a Região do Vale do Taquari onde, em 1883, 5 anos após ter tomado posse o Juiz Municipal Dr. João Theophilo Marsillac, este fora agredido pelo delegado de polícia local, membro da elite fundiária ${ }^{46}$. O rompimento com o grupo não foi fácil, mas, se no caso das apropriações indevidas, de terrenos públicos, o Estado não puniu tais abusos, indiretamente ele se beneficiou pelas duas faces da ação. Primeiro, ao permitir, ou simplesmente ignorar, as grilagens e as concessões clientelísticas, a Coroa estava garantindo a inserção destes agentes na sua estrutura (necessária à afirmação de domínio e propriedade). Depois, estava, indiretamente, garantindo a execução do projeto do Estado de fazer avançar as áreas coloniais sobre as regiões de domínio da elite fundiária na metade norte sul-rio-grandense, uma preocupação antiga do Governo, o que criava uma base de apoio a este e também pela urgência de defender uma fronteira beligerante ${ }^{47}$.

Desta forma, o Governo central renunciava, aos proprietários locais, o controle sobre a conservação e a comercialização das terras públicas. Enquanto a Lei de Terras procurava, nas suas linhas e entrelinhas, barrar as apropriações indevidas, o Regulamento de 1854 abria caminho a estas, sejam caminhos lícitos ou ilícitos, baseados nas redes de influência, nas quais estavam

\footnotetext{
${ }^{45}$ FERREIRA, Mariluci Melo. Tramas de poder: disputas políticas nos Campos de Cima da Serra/RS (1850-1880). Passo Fundo: Ed. da UPF, 2004.

${ }^{46}$ LIMA, José Antonio de Souza. Relatório com que S. Excia. o Snr. Conselheiro José Antonio de Souza Lima passou a administração da Provincia do Rio Grande do Sul em 11 de junho de 1883 ao Exmo. Snr. Dr. Meandro Rodrigues Fontes $1^{\circ}$ Vice-presidente. Porto Alegre: Typ. do Jornal do Commercio, 1883.

${ }^{47}$ No que se refere aos aspectos políticos da imigração na metade norte do Rio Grande do Sul ver CHRISTILLINO, 2004, op. cit.
} 
inseridos os possuidores de terras, ou seus interessados. Portanto, não foi a Lei totalmente ignorada, pelo contrário, foram utilizados vários dispositivos da sua regulamentação, para tais apropriações, mas se ela dava ampla margem de ação aos grileiros, ao mesmo tempo em que garantia o apoio destes à Coroa, pois os mesmos necessitariam do aval do Estado, em última instância, para a realização dos seus objetivos. No caso da Província de São Pedro do Rio Grande do Sul, o principal objetivo da Coroa era a defesa das fronteiras brasileiras com o Uruguai e a Argentina. Na década de 1850, a questão central era derrotar o presidente argentino Rosas, cujo conflito exigiu um grande esforço bélico. Neste período, e também nos posteriores (especialmente na Guerra do Paraguai), era muito mais importante, para a Coroa o engajamento dos chefes militares da Guarda Nacional, e seus contingentes, do que a preocupação com áreas de terras devolutas, que estavam sendo apropriadas por membros da elite local. Muitos deles compunham aquelas forças. Barrar essas apropriações poderia fazer com que, muitos daqueles, não marchassem às fronteiras contra Rosas e, mais tarde, contra Solano Lopez. Esta questão era muito mais importante para a Coroa do que a incorporação de terras que, uma vez comparadas com a totalidade das reservas do Governo, eram insignificantes. O papel da burocracia foi fundamental neste processo. Aos burocratas do primeiro escalão da monarquia, coube a tarefa de angariar aliados à base do apoio político da Coroa. Aos demais componentes da burocracia do Império e à da esfera local, constituída a partir da aplicação da Lei de Terras, restou um habilidoso trabalho, que buscava a permanência e a ascensão, nos postos burocráticos conquistados, não contrariando, diretamente, os interesses do Estado e, principalmente, os da elite fundiária, a qual devia, em muitos casos, o seu emprego. Estava aberto o caminho aos especuladores e grileiros, mesmo que entre as curvas e desvios da burocracia.

\section{Referências bibliográficas}

ALMEIDA, Manuel Antônio. Memórias de um sargento de milícias. Edição crítica de Cecília Lara. Rio de Janeiro: Livros Técnicos e Científicos Editora, 1978.

CANDIDO, Antônio. Um funcionário da monarquia: ensaio sobre o segundo escalão. Rio de Janeiro: Ed. Ouro Sobre Azul, 2002.

CARDOSO, Fernando Henrique. Capitalismo e Escravidão no Brasil Meridional: o negro na sociedade escravocrata do Rio Grande do Sul. Rio de Janeiro: Paz e Terra, 1977.

CARVALHO, José Murilo de. A construção da ordem: a elite política imperial/ Teatro das sombras: a política imperial. 2.ed. Rio de Janeiro: Editora da UFRJ, Relume-Dumará, 1996. 
CHRISTILLINO, Cristiano Luís. Estranhos em seu próprio chão: o processo de apropriações e expropriações de terras na Província de São Pedro Do Rio Grande do Sul (o Vale do Taquari no período de 1840-1889). São Leopoldo, UNISINOS, 2004. Dissertação (Mestrado em História), Centro de Ciências Humanas, Universidade do Vale do Rio dos Sinos, 2004.

FERREIRA, Mariluci Melo. Tramas de poder: disputas políticas nos Campos de Cima da Serra/RS (1850-1880). Passo Fundo: Ed. da UPF, 2004.

GRAHAM, Richard. Clientelismo e política no Brasil do século XIX. Rio de Janeiro: Editora da UFRJ, 1997.

IVO, Isnara Pereira. Poder local e eleições na imperial vila da Vitória durante o século XIX. In: Edições UESB, Vitória da Conquista-BH, v. 01, n. 01, 2001, p. 201-223.

MOTTA, Márcia Maria Menendes \& PIÑEIRO, Theo. Voluntariado e universo rural. Rio de Janeiro: Vício de Leitura, 2001, vol. 1, p. 75-91.

MOTTA, Márcia Maria Menendes. Nas fronteiras do poder: conflitos de terras e direito agrário no Brasil em meados do século XIX. Rio de Janeiro: Vício de Leitura; APERJ, 1998.

PADOIN, Maria Medianeira. Federalismo gaúcho: fronteira platina, direito e revolução. São Paulo: Companhia Editora Nacional, 2001.

PICCOLO, Helga Iracema L. Coletânea de discursos parlamentares da Assembléia Legislativa de São Pedro do Rio Grande do Sul: 1835/1889. Porto Alegre: Assembléia Legislativa do Estado do Rio Grande do Sul, 1998.

SCHIEROLT, José Alfredo. Revolução Federalista no Vale do Taquari. In: Anais do IV Simpósio da História da Imigração e Colonização Alemã no Rio Grande do Sul. São Leopoldo: Rotermund, 1987.

SECRETARIA da Agricultura RS. Coletânea da Legislação das Terras Públicas do Rio Grande do Sul. Porto alegre, 1961, p. 13. 